\title{
Use of Educational Technology in Special Education: Perceptions of Teachers
}

\author{
Kursat CAGILTAY \\ Computer Education and Instructional Technology, Middle East Technical University, 06800, \\ Ankara, Turkey. \\ Hasan CAKIR \\ Computer Education and Instructional Technology, Gazi University, 06500, Ankara, Turkey. \\ Necdet KARASU \\ Special Education, Gazi University, 06500, Ankara, Turkey. \\ Omer Faruk ISLIM* \\ Computer Education and Instructional Technology, Kirşehir Ahi Evran University, 40100 \\ Kirsehir, Turkey.
}

\section{Filiz CICEK}

Computer Education and Instructional Technology, Middle East Technical University, 06800, Ankara, Turkey

\begin{tabular}{ll}
\hline \hline Article history & The purpose of this study is to understand opinions, experiences, \\
01.11 .2019 & and perceptions of special education teachers with educational \\
Received in revised form: & technologies. This study is a part of a larger project that targets \\
29.11 .2019 & developing instructional materials for students with special needs, \\
& their teachers and parents. Needs analysis was conducted to \\
Accepted: & understand the current situation. Participants were 27 teachers in 6 \\
30.11 .2019 & different schools from Ankara, Turkey. The data were collected \\
Key words: & using semi-structured interviews and analyzed by taking content \\
\hline Turkey, teaching materials, & analysis approach. The results indicated that teachers use of \\
& technology for instructional purposes was very limited due to lack \\
& of infrastructure and appropriate material. Teachers believe that \\
& technology use in classroom improves quality of educational \\
& outcomes and job satisfaction. In relation to learning new \\
& technologies for educational use, teachers do not feel obligation to \\
& learn new technologies unless it becomes a necessity. Moreover, \\
& there is a large potential to develop materials in special education \\
& field with new technologies. Along with developing materials for \\
& students using bodily movement detection, touch screen, and smart \\
& toys technologies, it is also necessary to train teachers how to use \\
& them in classroom and to train parents to continue student's \\
& education at home. Materials could support teachers while teaching \\
& self-care skills, social skills, and cognitive concepts. Moreover, \\
\hline \hline
\end{tabular}


they help students to reinforce and transfer these skills and knowledge to new contexts by providing many practice-feedback and variety of real contexts.

\section{Introduction}

With the development of computers, technology in education has dramatically changed and variety of opportunities emerged to support teaching and learning processes. As processing and storage capacity of computers improved, their role of supporting teaching and learning has evolved. Utilizing computers to deliver the instructional content with supportive multimedia elements such as interactive images, videos, animations, simulations, and computer games made computers as standalone supporter of students and teachers ( Hew \& Cheung, 2010; Means, Toyama, Murphy, Bakia, \& Jones, 2009; Ma \& Nickerson, 2006; Penuel, 2006; Rutten, van Joolingen, \& van der Veen, 2012). Continuous developments in the information and communication technologies (ICT) had its share in the instructional technologies as well. While nowadays much of the research focuses on instructional technologies to be utilized to improve active learning and interactions among teachers and students in regular learning environments, teachers and students from special education group have not much benefited from these developments. Many of the technologies in the special education field were called as assistive technologies (Edyburn, 2013; Okolo \& Bouck, 2007). The Assistive Technology Act (2004), which was signed by the US Government in October 25, 2004, defines assistive technology as "Any item, piece of equipment or product system, whether acquired commercially off the shelf, modified, or customized, that is used to increase, maintain, or improve functional capabilities of individuals with disabilities". The assistive technology is an umbrella term that covers walkers, wheelchairs, hardware, software and any kind of equipment that helps and ease the life of people with disabilities. These technologies give chance disabled people to have independent life and involve in the society (World Health Organization, 2012)

Current technology holds great potential for teaching and learning activities in special education area. Alternative ways of interaction with computers, fast-responding processors, high definition animated graphics, and communication/collaboration over the internet facilitate better learning environments for students, teachers, and parents. Game consoles such as Nintendo's Wii and Microsoft's Xbox and tablets provide different modes of interaction with computers than traditional mouse-keyboard model. In traditional model, the user gives commands to computers by using keyboard and mouse, however, using keyboard and mouse requires hand and eye coordination to be used effectively (Laursen, Jensen, Garde \& Jargensen, 2002), for which not all special education students may have such skills (Shimizu, Yoon, and McDonough, 2010). Instead of using mouse and keyboard, using body gestures or touch screens to interact with computers provides better interaction and user experience results (Findlater, Froehlich, Fattal, Wobbrock \& Dastyar, 2013; Lee, Isenberg, Riche \& Carpendale, 2012; Wachs, Kölsch, Stern \& Edan, 2011).

Students with special learning needs or students with developmental disabilities can be considered as a type of students with low academic ability students. Some of the general learner characteristics include short attention span, low capacity of working memory, need for repetitious practice and feedback sessions, and difficulties to make connections between events and characters in the same story (Bender, 2008; Taylor, Richards, \& Brady, 2005; Wenar \& Kerig, 2006). Typical instruction for these students is highly structured, provides strict guidelines, progresses with small steps, repeats practices and feedback sessions as many times as students need (Kirk, Gallagher, Coleman, \& Anastasiow, 2011; Smith, Polloway, Patton, \& 
Dowdy, 1990). This type of instruction can be developed with educational technology tools such as computers, tablets, or game consoles. Research shows that special education students benefit from educational technology, especially in concept teaching and in practice-feedback type instructional activities (Carter \& Center, 2005; Hall, Hughes, \& Filbert, 2000; Hasselbring \& Glaser, 2000). Generally, video based, or keyboard-mouse interaction type computer-based technologies have been utilized in special education cases, which have very limited student interaction and feedback capacities. However, computer technologies that allow students to interact via alternative channels such as body gestures or touch screens have potential to produce better learning results for students (Hwang, Wu \& Fan-Ray, 2013).

Although technology in education brings out certain positive results in terms of educational outcomes, teachers play a key role to facilitate the diffusion and the use of educational technology (Brinkerhoff, 2006; Inan \& Lowther, 2010; Zhao \& Frank, 2003). Much of the technology with instructional purposes in schools are used by teachers. Whether it is for the purposes of presentation, record keeping, communication, or information search, members of the teacher body in an educational institution are the primary users of the technology in their classrooms (Bebell, Russell, \& O’Dwyer, 2004; Hernandez-Ramos, 2005; Persichitte, Tharp, \& Caffarella, 1997; Smerdon et. al., 2000).

There are certain factors that affect instructors' use of technology in teaching process. Ertmer (1999) classified these factors into two groups as internal and external factors. Internal factors were identified as teachers' attitudes, motivation and competency towards using technology in the classroom and external factors were identified as curriculum, technical infrastructure, training, and school culture. Literature has large number of studies that investigated these factors on variety of teaching subjects (Abbitt, 2011; Bingimlas, 2009; Ertmer, 2005; Higgins \& Spitulnik, 2008; Mumtaz, 2000; Niess, 2005; Polly, Mims, Shepherd, \& Inan, 2010), however most of them are focused on mathematics, science, and elementary education. Special education and teachers in special education field have been generally ignored or studied very little in technology integration studies (Edyburn, 2001; Smith \& Okolo, 2010; Twyman \& Tindal, 2006). There is especially a knowledge gap in the literature about thoughts of special education teachers' attitudes and opinions about using technology for students with special learning needs, especially computer-based materials that support alternative ways to interact with computers.

\section{Significance of the study}

There is a growing interest towards developing computer-based instructional materials for students with special learning needs in educational research community yet our knowledgebase about how special education teachers integrate the computer technologies in special education classrooms is very limited (Seo \& Bryant, 2009; Stetter \& Hughes, 2010). Before designing any sorts of instruction, instructional designers must have good understanding of needs and capabilities of potential users of the instructional materials (Morrison, Ross, Kemp, \& Kalman, 2010). It is especially more important in special education context in which teachers' needs, attitudes, competencies, and utilization of instructional technologies in their classrooms have been largely ignored in terms of designing computer supported instructional material.

The purpose of this study is to understand needs and attitudes of special education teachers towards computer based instructional materials. The findings of this study have potential to shed light on design and development of computer based instructional materials that 
specifically meet needs of students with special learning needs and their teachers.

\section{Method}

\section{Context}

The study is an educational technology usage project that targets students with special learning needs, their teachers and their parents. The purpose of the project is to develop three major educational technologies that help all three parties to improve teaching and learning experiences in school and at home. The first products involve computer games that can be controlled by bodily movements, it aims to teach and practice kinaesthetic and self-care skills to students. The second products involve tablet and interactive table that enable students to learn and practice matching, numbers, letters, colours, and such concepts. The third products involve smart toys that help students to learn and practice storytelling and communication skills using conventional computers. The products of the project aim to help students, their teachers, and their parents in two dimensions. First, the products can be used in schools to help students and teachers to engage with educationally meaningful activities to learn concepts and skills. Second, as special education needs to be continued at home under parents' supervision, these technologies are hoped to help the students and their parents to practice at home for what they learned in school. Hence, parents can support work in school by practicing concepts and skills at home.

In the context of this study, developed educational technology materials are to be mainly utilized by teachers in special education classes. Therefore, it is important to understand their competency levels of technology use and their attitudes towards technology use in their classrooms with the target group. Another part of the study's context is special education schools in Turkey. These schools focus on students with special learning needs with eight students and individual study classrooms. The curriculum and teaching materials are provided by Ministry of National Education and teachers apply pre-set goals and objectives by the curriculum in these schools. Each student has a learning goals agenda to accomplish during the school year. Depending on the students' learning ability level, they can be put in an 8-student classroom or they work with teachers individually. In order to provide equal access to educational opportunities, the schools targeted students with special learning needs were opened nearly all large and small cities. The schools that were cooperated with this research project located in a highly populated urban area. Like all other schools, these schools were also equipped with computer labs, internet connections, smart boards, and projectors that were supplied by the Ministry of National Education or bought by parent unions.

\section{Research Methodology}

The main purpose of this qualitative study is to understand perception of special education teachers towards use of technology in their classes and how they use technology in their classes. The qualitative studies aim at in depth analyzing and defining a case (Fraenkel, Wallen, \& Hyun, 2012; Yin, 2011) that reflects the views and opinions of participants (Yin, 2011). In this manner, a need analysis was conducted which provides information about current and desired state of the situation or phenomenon under investigation based on participants' opinions. Main data collection method was semi-structured interviews with special education teachers and administrators in schools. Collected data were transcribed and coded with utilizing constant comparative approach of qualitative data. 


\section{Participants}

Participants of the study were special education teachers and administrators who work in urban schools that serve students with special needs. Since schools that serve and teachers that teach students with special needs are rare in comparison to other public schools, the research team took referral sampling approach to identify teachers to interview. For this study, research team visited the participating schools and gave a brief presentation about educational technology in special education and details about the aforementioned educational technology project. The project team also mentioned the need for interviewing teachers to understand current and desired classroom technologies, teachers' abilities for, and attitudes towards use of technology in their teaching process. Volunteered teachers were signed up for the interviews and they were asked whether they can refer any other teachers who use technology in their classrooms.

22 teachers and five administrators were interviewed in six schools. Among these schools, two schools were funded and operated by the Ministry of National Education and rest of the schools were funded by the Ministry of National Education but operated by private enterprises. All schools were located in urban region of the city. 22 participants were female and rest of them were male.

The composition of participated teachers shows a great variation in terms of major and teaching experience. In Turkish Universities, schools of education with special education departments are limited in numbers, not all interviewed teachers held a major degree in special education. In order to teach in special education classes, teachers with elementary education or early childhood education majors were trained in certificate programs and assigned as special education teachers in these schools. Among the interviewed teachers, seven teachers held degree from special education major in undergraduate education and rest of the teachers held a certificate degree of special education.

Teaching experiences of interviewed teachers are also varied in terms of teaching subject and year of teaching experience in special education. Since some of the teachers started their teaching career as elementary or early childhood teachers, their teaching experience consists of special education or other education. Among the interviewed teachers, seven of them fully special education teaching experiences in their career and it was approximately 11 years in average. Other teachers had approximately five years of special education teaching experience apart from their elementary or early childhood education teaching experiences. This was an expected situation in Turkish special education context since departments that specialized on only special education in school of educations are not widespread, and the number of graduates is not sufficient to fill all the positions in special education schools. Therefore, Ministry of National Education grants early childhood education or elementary education teachers with special education degrees after completing a certificate program. Some participants in this study started teaching special education schools after teaching in elementary education schools.

Prior to interview questions related to use of technology in classrooms, the research team asked teachers about how competent they felt about certain computer use skills such as operating a computer, using word processors, presentation software, surfing and searching on the Internet, adding or removing hardware, and diagnosing a technical problem on computers. Majority of participants are comfortable with many of these skills except adding and removing hardware pieces and diagnosing a technical difficulty on computers. The main reason for that situation could be as the years of teaching experience indicates, all teachers are coming from a generation that is already familiar or utilizes information and communication technologies in their daily 
lives.

\section{Data Collection}

In order to collect data from teachers, semi-structured interviews were conducted. An interview form was developed to guide the interview and help the participants stay focused on technology use in special education.

The interview protocol was developed by the research team and went through several improvement steps to assure the reliability, validity, and understandability of the questions. As a first step, the research team developed interview questions based on needs analysis studies that took place in the literature and from researchers' previous experiences. Then these questions were discussed with experts from special education and educational technology fields. Based on the recommendations from the experts, the interview questions were grouped, and small changes were made. Then a pilot interview took place with a special education teacher to test the interview protocol in terms of readability of the informed consent form, clarity of the questions, and length of the interview. After finalizing the interview protocol, research permission was obtained from the ministry of national education. Interviews were conducted by a 4-person research team. Before starting the interviews, the research team was trained about how to start, continue, conclude, and summarize the data obtained from the interview. All interviewers had the same procedure to apply during the interview process, which contributes to ensure the reliability of the data collection.

In average, interviews lasted approximately 40 minutes per participant. All interviews were tape recorded after informing the participants and obtaining their consent to do so. After each interview, interviewer summarized thoughts and reflections related to the information obtained from the participant. All interviews were transcribed by the research team to do content analysis.

\section{Data Analysis}

The main data analysis method was to content analysis of the data. Content analysis is a qualitative data analysis method that helps researchers to understand major thoughts and connections between them within a given data set. It starts with determining free thoughts, or commonly called codes, within the data set and continues to group and connect these codes meaningfully to plot the meaning behind the data. According to Creswell (2007), coding is the hearth of qualitative data analysis. Coding is separating raw text into small meaningful chunks while keeping the relationship between them. The main aim of coding is to analyze, differentiate and compare the data (Miles \& Huberman, 1994). Researchers may utilize different coding strategies: creating a brand-new coding table or using a pre-determined coding table from the literature (Creswell, 2007, 2009; Miles \& Huberman, 1994).

In order to analyze the data, the research team transcribed all interviews into separate file for each participant. After reading all data, a meeting was held to generate common understanding within the researchers. This is an important step since an analyzer generates codes and assigns them certain meaning, which later may affect consistency amongst the coders. After generating the codes an analyzer and an expert worked together to discuss the meaning of codes and to place these codes under larger categories.

Since a researcher can be both an interviewer and an analyzer, it is a challenge to ensure objectivity in any given qualitative research project. One of the difficulties related to content 
analysis of qualitative data is to ensure reliability and validity of the data analysis process. In order to assure consistency among analyzers, regular group meetings were held to discuss the meaning of the data and the codes generated. Finally, part of the data was coded by two coders to understand the consistency between coders. It was calculated that two coders were consistent at $80 \%$ to assign thoughts to codes in the data set.

\section{Findings}

Results of the analysis showed that thoughts in the interview data collected from special education teachers can be grouped in four main categories. They can be listed from the most mentioned to least mentioned as (1) Teachers' technology use, (2) Necessary technologies and materials, (3) Effect of technology on educational outcomes, and (4) Teachers' attitudes towards technology.

Table 1. Distribution of codes among participants

\begin{tabular}{lll}
\hline Category - Code & $\begin{array}{l}\text { Number } \\
\text { Participants }\end{array}$ & $\begin{array}{l}\text { of } \\
\text { ideas }\end{array}$ \\
\hline Teachers' Technology Use & 16 & 30 \\
Current technologies & 12 & 23 \\
Using technology in schools & 14 & 20 \\
Monitoring student performance & 13 & 20 \\
Difficulties with technology & 11 & 14 \\
Internet resources & & \\
\hline Necessary Technologies and Materials & 13 & 33 \\
Technologies that can be developed & 11 & 17 \\
Areas to develop technological materials & & 17 \\
\hline Effect of Technology on Educational Outcomes & 11 & 16 \\
Generalization and transfer & 12 & 16 \\
Group training & 15 & 13 \\
Motivation & 11 & \\
Job satisfaction & & 22 \\
\hline Teachers' Attitudes towards Technology & 15 & 20 \\
Interest to use technology & 18 & 10 \\
Perceptions of technology competencies & 7 & \\
Interest to learn new technologies & & \\
\hline
\end{tabular}

"Teachers' technology use" category gathers the ideas from the data about what kind of technologies and how special education teachers use them in their teaching activities. Five codes related to teachers' technology use were grouped under this category, all of which help us to understand teachers' experiences with technology use. The second major category, "Necessary technologies and materials", gathers codes for technologies and materials that are needed in teaching special education students. Generally, teachers stated their thoughts about what materials and technologies can be used to teach certain concepts and skills. The third major category, "Effects of educational technology on educational outcomes, contains codes 
related to how use of educational technology affects students' educational outcomes such as engagement, learning, generalization, and transfer of newly introduced knowledge and skills. Finally, the fourth major category, "Teachers' attitudes towards technology", includes codes related to interviewed teachers' attitude and motivation towards use of computer technologies in their daily life and in classroom for teaching and learning activities. Following section explains the major categories and codes nested under them in detail.

\section{Teachers' Technology Use}

Under this category, codes that are related to current technologies that teachers use in their daily life and classroom are explained. All teachers mentioned they are familiar with contemporary technologies. By contemporary technologies, they mean desktop, laptop, and tablet computers, the Internet, smartboards, projectors, and cell phones. In addition to that these technologies are available to teachers at schools to use them in their classrooms, teachers use them, especially computers, internet, and cell phones, at their home too. This part of the data shows that teachers have required hardware, infrastructure, and knowledge to use the technologies.

The second most mentioned thought was monitoring student performance with technology. In special education classes, it might be highly beneficial monitoring and documenting student performance within certain time intervals. Teachers use technology in monitoring student performance during the performance monitoring activity, student videos are recorded, then teacher fills a behavior checklist. These checklists are prepared in computers and teachers complete them either using their laptop or desktop computers. Although teachers mentioned about recording students' video to understand the student's progress on learning concepts or skills between measurement points, they usually do it with observations rather than video recording.

The third code is related to how teachers use and would like to use technology in their schools and classrooms. Teachers stated that they usually use desktop or laptop computers for personal tasks, getting print outs, and rewarding students with computer games. They also use smart boards for teaching and practicing concepts. They use technology for rewarding students after successfully completed learning tasks or giving feedback on their learning process. This is stated in a teacher's comment related to using smartboard to tell a story about a concept and then allowing students to answer questions related to newly learned concept while the computer provides feedback to students.

\footnotetext{
"...we were listening to the story. At the end of the story were questions related to it. They were answering these questions by touching. For example, let's say blue car. With whom did the blue car meet? answer was yellow car, then they were touching yellow car. Or a page was opening, show the land vehicles. When they touched a correct vehicle, an applause sound was started. When they touched an incorrect vehicle a sulky voice like "yaa" was heard. They loved this activity".
}

The fourth code under this category is related to teachers' experienced difficulties with using technology in their classrooms. When it comes to difficulties to use technology in classrooms, teachers stated two major obstacles, first, financial difficulties to obtain and maintain the technology and, second, lack of materials that are usable in special education classes. Additionally, few teachers mentioned about lack of training to use technological tools in the classroom. Obtaining and maintaining technology for schools is a financial issue and schools largely depend on funds from government to operate and pay teachers' salaries. Therefore, 
neither many funds are allocated to equip the classrooms with technology nor do teachers have sufficient salary to obtain technology with their own funding. A teacher states that "First of all they need to have the financial power to obtain these devices. It is not easy for teachers to obtain them considering teachers' salary situations" to sum up the situation. The second major issue with the technological difficulties is lack of educational materials that are developed for audience in special education. Teachers stated that they can find the materials on the Internet or from other sources, but they have to make certain modifications or use limited parts of the materials, which is not compatible with the special education curriculum. A teacher stated that

"...there is lack of technological materials that are useful for us, I think this is the biggest barrier. The materials we found on the internet were developed for normal children, I mean the kids with normal intelligence levels. I cannot find materials for students with learning disabilities".

Another teacher supported this opinion with stating;

"...in terms of content, I mean we don't have very well-developed contents that are related to the special education. Our software was good but in very very limited field, they needed to be improved. It is controversial claim that the material we have is appropriate for special education. Before we use them, we need to make some simple changes or pause them while presenting to the students. Colors, brightness or other features of the material sometimes are not appropriate, I mean the kids cannot see easily"

The fifth code is related to the internet resources that teachers find useful or benefit from. All teachers are competent to use computers with the Internet connection in order to find teaching resources for themselves and for their students. However, these resources are not sufficient for special education teachers. The materials are usually developed for early childhood education teachers. Additionally, some teachers mentioned low quality of materials in Turkish portals, therefore they prefer to use visuals from foreign websites. A teacher stated that situation as

"I am using foreign sites when I do the research on the Internet. I think the visuals are especially in better quality in those sites. Instructional materials, visuals, and daily plans that are recently uploaded to the websites were send me as e-mails".

\section{Necessary Technologies and Materials}

The second category of thoughts is related to materials and technology that help teaching and learning process in special education classrooms. Teachers' ideas consist of two codes in this category; Developmental areas that technology can be used and technologies that can be developed for these areas.

The first code in this category is developmental areas that technology can be used in special education. During the interviews, teachers were presented a video that introduces educational technologies that are developed in the project. Then they were asked to explain what areas can be taught to students in special education using these technologies. Majority of the teachers agreed that explained technologies can be used to teach cognitive, psychomotor, and affective domain. In cognitive domain, they can be used to teach concepts, numbers, letters, and comparisons such as tall-short, big-small, or directions left-right, top-bottom etc. In psychomotor domain, teachers especially emphasized to teach the basic skills for self-care such as cleaning the face, hands, arms, feet, and legs. Developed technologies in the project can be used to teach self-care skills for these students. Finally, these technologies can be used to teach 
topics in affective domain such as greeting, showing/responding emotions, and socialization skills. One of the teachers mentioned that students can be taught how to dance in order to socialize or communicate with other students. A teacher stated that

"...social module can be utilized. For example, dancing, with the game programs that can be developed with kinect technology, students can participate individual or group dancing activity. It can support the socialization of students with learning disabilities. Interactive touchpad table can be used in concept teaching, more-less, tall-short, opposite concepts like white-black, these concepts can be taught."

In relation to the first code, the second code in this category is technologies that can be developed to use in these areas to teach certain concepts and skills to students. Teachers gave examples about how technologies developed in the project can be used. A teacher gave an example for how kinect technology can be used in special education by stating "...this is especially helpful for physical education classes, also in teaching body parts". Again, teachers emphasizes that it is important to teach self-care skills and behavior control in public areas. A teacher state this as

"...as I said it is not important to know tons of concepts for the kid if that kid cannot go to toilet by himself or cannot eat his meal. If his mom cannot take him to a movie theater or shopping center because of behavioral problems, it is not important for him to use technology"

\section{Effect of Technology on Educational Outcomes}

Using educational technology in any kind of classroom is proved to have certain impact of educational outcomes such as motivation, engagement, achievement, and transfer. In special education classrooms, the impact of technology is expected to more than regular school classrooms, therefore teachers are asked about whether and how using introduced educational technology by this project in their classrooms can impact their students in broader sense of educational outcomes. Content analysis showed that teachers' thoughts are gathered in four codes; Motivation, job satisfaction, group training, and generalization and transfer.

The first code is associated with student motivation. All teachers mentioned that when a classroom technology is introduced to teaching activities such as an animation movie, a computer game, or interactive graphics, students are more motivated to stay in the classroom and obey the teachers' instructions. Educational technology in the classroom improves students' motivation and their eagerness to do learning tasks therefore technologies that are developed with the project can help to improve student motivation. A teacher stated that "...it is even higher. Because they quickly get bored with paper. But computers are more motivating so they are eager, they can learn faster. Since it is visual, their cognition expands, and attention span lengthens". Rewards that are carried with technology helps students to stay focused on their learning tasks and they become more obedient to teachers' instructions. A teacher showed that by stating "...for example when I said to one of students that he could watch an animation movie next week, we finished a 40-minute class easily without any problem".

The second code is related to teachers' job satisfaction. One of the main problems in the special education is giving practice and feedback to students in numerous times. That may wear off teachers soon in their job and decrease their teaching quality. A teacher states this situation with "... as I said repetitions makes us worn off. Because our feedbacks are getting weaker, sometimes I feel that when I speak, the number of words I use are getting decreased". When teachers use technology 
in their classroom, they would feel equipped with on-target materials and more confident about teaching activities. Also, students are more engaged with the instruction and they are more obedient to teachers' instructions, which all together could improve teachers' job satisfaction.

The third code gathers the thoughts about impact on group training. In relation to the first code that states students are more motivated and engaged with the presence of technology in the classroom, teachers stated that technology helps them to do group training sessions easier than without technology. Although group training means different for all teachers in the context of special education, teachers at least agree on that students learn from each other during the group training sessions even though these could be how to touch a touch screen. A participant stated

"...well let me put it this way, for example the other day, this student was touching red balloons, I thought of showing him how to burst balloons in the screen but another student started to burst them and the other one was watching, he understood that 'I am going to burst only red ones', they learn from each other".

Finally, the fourth code is related to generalization and transfer of newly learned concepts and skills. One of the most difficult topics in special education is to help students to generalize and transfer the newly learned concepts and skills to contexts in real life. Although the students may show a variety of skills for generalization and transfer, they usually need many varieties of examples and repeated practice-feedback sessions in real life contexts. A participant stated this situation as "...generalization is very difficult for our school. Generalization can change based on individual characteristics. Some of the students can do by themselves, some of them requires long periods of individual tutoring". Preparing these examples and context for teachers is not easy job for all situations, a participant stated this as

"...in order to integrate kids to daily life, I bring things from real life as much as possible. For example, I worked on money or shopping in the daily life. I try to create a shopping environment in classroom like providing money, cashier, getting change etc. whatever I can bring to classroom. Of course, these are very difficult for me to create so it is very difficult for me".

For effective generalization and transfer, some participants stated that students' training needs to be continued with the help from his/her family in the house as well with real life contexts. A participant stated this as "...Definitely you teach in the game, aah, that's why in realistic context, I want him to maintain the knowledge or skills in his mind for a long time. When I talked to the family, I tell them what I did and what I expect them to do in the home". Some participants stated that using technology for repeated practices with variety of examples helps students to generalize the knowledge and skills and transfer them into new contexts. According to participants, technology can provide these varieties for examples and contexts to teach concepts and skills. A participant stated that "...I use technology to ensure transfer of knowledge and skills and it's worth to use. I overuse examples and have them watch related videos at the end of classes".

\section{Teachers' Attitudes towards Technology}

The final category for teachers' thoughts about using technology in the classroom is teachers' attitudes related to technology and using it in education. One of the important factors for successful technology integration in schools is teachers' attitudes towards using technology for education. Analysis showed that teachers attitudes can be grouped under three codes.

The first code is teachers' interest towards technology. Almost all interviewed teachers showed 
positive interest towards using technology in their daily life and in their teaching. Most of them follow the technology within their budgets' and work schedule limits and expressed interest to learn new technologies whenever possible. A participant stated that "...certainly there must be difficult parts of technology, but I think it is learnable. However, I will be held back if I stop learning it, that's why I need to keep learning and professionally develop myself"

Some participants expressed their reasons to use technology in their job because it becomes easy to access information and teaching materials by using the internet and communication technologies. A participant stated that

"...I mean I can reach information faster. For example, I was preparing my teaching materials by myself before computers such as cutting, drawing and coloring cards related to jobs but now I can reach these materials with one click on touch screen. I save time and effort"

The second code is associated with perceptions of computer use competencies of teachers. This code mainly stems from a question asked during the interviews which aimed to learn about how teachers see themselves in terms of computer use competencies. Most of the teachers stated that they know how to operate a computer and connected hardware to complete their daily or jobrelated tasks. These tasks do not require advanced computer knowledge such as preparing a document in word processing documents or surfing and searching on the internet. However, if they encounter a problem with the operating system or hardware, they need help from more experienced people around them. A teacher commented on whether her computer competencies are sufficient for her as below;

"...yes, if they support me. If they show me how to install a software, I can learn it by trial and error methods. Previously I was afraid of using computers but now at least I know that my files are not running away when I don't see them on my computer. I found it very helpful to ask someone knowledgeable about computers".

Finally, teachers' interest to learn new technologies is the last thought in this category. Not many of the teachers mentioned about learning new technologies, but the ones stated opinions about learning new technologies emphasized that they learn new technologies when they must complete their daily job tasks. A teacher stated that "...I use technology to meet my needs in daily life. I don't need to learn more about them". This is an indicator that teachers in special education are not so much keen to follow technological development for teaching or other tasks. This is a situation that stems from lack of educational technology tools and materials for special education therefore teachers do not feel a need to keep up with the technological innovations and another reason for that situation is financial limitations to access and obtain latest technology either for daily or teaching tasks.

\section{Discussion and conclusion}

The purpose of this study was to understand perceptions of special education teachers with educational technologies and their perceptions about educational technologies that would be developed by the project that aimed to develop educational materials for special education teachers and students. As the first step in the project, by taking a qualitative research approach, a needs analysis was conducted to analyze the current and desired state of technology use in special education classrooms. Data collected from teachers in special education were analyzed using content analysis technique. As a result of analysis, four major themes appeared from the data. First, participants commented on their technology use in their classrooms. Teachers 
usually use technology to keep student records and access teaching materials or information related to special education. They also use animations in computer or in video format. However, due to lack of infrastructure, educational material, and family's lack of access to technology, technology is not used as it should be in special education classes. One of the well documented barriers in technology integration is lack of access to the technological infrastructure and technology itself (Bingimlas, 2009; Pittman \& Gaines, 2015; Ertmer, 1999; Hew \& Brush, 2006). In contrary to the common belief about fast development of and wide access to the technology, lack of access to a functional technological infrastructure and technological devices persist as a barrier factor for technology integration for teachers in special education.

Second, teachers mentioned lack of materials specifically designed for special education students. They usually use part of the materials that are developed for early childhood education, which satisfies neither curriculum's nor teachers' requirements. Participants mainly emphasized that technology in special education can be used to teach concepts, communication skills, and self-care skills of students. This result emphasizes the importance of availability of appropriate computer-based materials for instructional purposes. Similar to the other fields of education, lack of curriculum-oriented computer supported instructional materials is still a barrier for use of technology in special education classes (Bingimlas, 2009; Shi \& Bichelmeyer, 2007). Third, participants stated that using technology in classroom improves the quality of educational outcomes for students as well as themselves. While it helps students to be kept motivated to complete learning tasks, it also helps teachers in practice and feedback sessions of students to improve their job satisfaction (Cheung \& Slavin, 2012; Larwin \& Larwin, 2011).

Fourth, teachers' attitude towards technology was positive and they do not hesitate to work with technology in their job or personal life related tasks. Teachers are eager to learn new technologies when they believe if that technology would help them in their job or daily life. However, due to financial limits and time constrains, they do not feel compulsion to learn new technologies unless it is inevitable. Teachers' use of technology in classroom is a highly researched area and one of the important factors on this is the curriculum approach used in the courses. Since the curriculum's approach is the major factor that determines the teaching and learning activities, it is also the major factor for how teachers use technology in the classroom. This finding concurs with the idea in the literature that teachers who need to work with a curriculum that encourages use of educational technologies are eager to learn new instructional technologies (Chen, 2008; Hew \& Brush, 2007; Lawless \& Pellegrino, 2007). Based on the findings from the study, it is clear that there is a large potential to develop materials for special education field. Along with developing materials for students using bodily movement detection, touch screen, and smart toys technologies, it is also necessary to train teachers how to use them in classroom and to train parents to continue student's education at home. Materials could support teachers while teaching self-care skills, social skills, and cognitive concepts and they help students to reinforce and transfer these skills and knowledge to new context by providing many practice-feedback and variety of real contexts (Fitzgerald, Koury \& Mitchem, 2008). Important point about educational technology materials that would be developed for special education is that these materials need to allow teachers and students to do many practices and provide informative feedback for students and teachers. Moreover, the materials need to be designed as close as possible to real life contexts in which target skills or knowledge are used.

Although teachers believe that technology can help to improve teaching and learning in special education, it is clear that there is an expectation from teachers' community of special education that professional development for teachers to teach with technology is needed. Along with developing materials to meet students' special needs, designing professional development 
programs to orient teachers about how educational technology can help special education and how to use technology in special education classes in a more systematic way is necessary for schools.

As in any educational study, this study is also bound with certain limitations. Although participants interviewed in this study were selected by using referral sampling method, not all teachers' major were special education. Some participant teachers were originally elementary teachers or early childhood education teachers, after completing a certificate program they became special education teacher, therefore they may not be as experienced as special education majors. Another limitation was weak technological infrastructure of special education schools. Since there were not sufficient hardware and supporting educational software, participants may not be as experienced as teachers in other schools in terms of using technology in classrooms.

\section{Acknowledgement}

This work was supported by The Scientific and Technological Research Council of Turkey (TUBITAK) under Grant Number 111K394

\section{References}

Abbitt, J. T. (2011). Measuring technological pedagogical content knowledge in preservice teacher education: A review of current methods and instruments. Journal of Research on Technology in Education, 43(4), 281-300.

Bebell, D., Russell, M., \& O’Dwyer, L. (2004). Measuring teachers' technology uses: Why multiple-measures are more revealing. Journal of Research on Technology in Education, 37(1), 45-63.

Bender, W. N. (2008). Learning disabilities: Characteristics, identification, and teaching strategies. Pearson/Allyn and Bacon.

Bingimlas, K. A. (2009). Barriers to the successful integration of ICT in teaching and learning environments: A review of the literature. Eurasia Journal of Mathematics, Science \& Technology Education, 5(3), 235-245.

Brinkerhoff, J. (2006). Effects of a long-duration, professional development academy on technology skills, computer self-efficacy, and technology integration beliefs and practices. Journal of Research on Technology in Education, 39(1), 22-43.

Carter, M. V., \& Center, S. E. (2005). Using PLATO with Students with Disabilities. Retrieved July, 30, 2017 from http://citeseerx.ist.psu.edu/viewdoc/download?doi=10.1.1.579.7716\&rep=rep1\&type= pdf

Chen, C. H. (2008). Why do teachers not practice what they believe regarding technology integration?. The Journal of Educational Research, 102(1), 65-75.

Cheung, A. C., \& Slavin, R. E. (2012). How features of educational technology applications affect student reading outcomes: A meta-analysis. Educational Research Review, 7(3), 198-215.

Edyburn, D. L. (2001). Critical issues in special education technology research: What do we know? What do we need to know? Advances in Learning and Behavioral Disabilities, $15,95-117$.

Edyburn, D. L. (2013). Critical issues in advancing the special education technology evidence base. Exceptional Children, 80(1), 7-24. 
Ertmer, P. A. (1999). Addressing first-and second-order barriers to change: Strategies for technology integration. Educational Technology Research and Development, 47(4), 47-61.

Ertmer, P. A. (2005). Teacher pedagogical beliefs: The final frontier in our quest for technology integration? Educational Technology Research and Development, 53(4), 25-39.

Findlater, L., Froehlich, J. E., Fattal, K., Wobbrock, J. O., \& Dastyar, T. (2013, April). Agerelated differences in performance with touchscreens compared to traditional mouse input. In Proceedings of the SIGCHI Conference on Human Factors in Computing Systems (pp. 343-346). ACM.

Fitzgerald, G., Koury, K., \& Mitchem, K. (2008). Research on computer-mediated instruction for students with high incidence disabilities. Journal of Educational Computing Research, 38(2), 201-233.

Hall, T. E., Hughes, C. A., \& Filbert, M. (2000). Computer Assisted Instruction in Reading for Students with Learning Disabilities: A Research Synthesis. Education and Treatment of Children, 23(2), 173-93.

Hasselbring, T. S., \& Glaser, C. H. W. (2000). Use of computer technology to help students with special needs. The Future of Children, 102-122.

Hernandez-Ramos, P. (2005). If not here, where? Understanding teachers' use of technology in Silicon Valley schools. Journal of Research on Technology in Education, 38(1), $39-64$.

Hew, K. F., \& Brush, T. (2007). Integrating technology into K-12 teaching and learning: Current knowledge gaps and recommendations for future research. Educational Technology Research and Development, 55(3), 223-252.

Hew, K. F., \& Cheung, W. S. (2010). Use of three-dimensional (3-D) immersive virtual worlds in K-12 and higher education settings: A review of the research. British Journal of Educational Technology, 41(1), 33-55.

Higgins, T. E., \& Spitulnik, M. W. (2008). Supporting teachers' use of technology in science instruction through professional development: A literature review. Journal of Science Education and Technology, 17(5), 511-521.

Hwang, G. J., Wu, C. H., \& Fan-Ray, K. (2013). Effects of touch technology-based concept mapping on students' learning attitudes and perceptions. Journal of Educational Technology \& Society, 16(3), 274.

Inan, F. A., \& Lowther, D. L. (2010). Factors affecting technology integration in K-12 classrooms: a path model. Educational Technology Research and Development, 58(2), 137-154.

Kirk, S., Gallagher, J., Coleman, M. R., \& Anastasiow, N. J. (2011). Educating Exceptional Children. Cengage Learning.

Larwin, K., \& Larwin, D. (2011). A meta-analysis examining the impact of computer-assisted instruction on postsecondary statistics education: 40 years of research. Journal of Research on Technology in Education, 43(3), 253-278.

Laursen, B., Jensen, B. R., Garde, A. H., \& Jargensen, A. H. (2002). Effect of mental and physical demands on muscular activity during the use of a computer mouse and a keyboard. Scandinavian Journal of Work, Environment \& Health, 215-221.

Lawless, K. A., \& Pellegrino, J. W. (2007). Professional development in integrating technology into teaching and learning: Knowns, unknowns, and ways to pursue better questions and answers. Review of Educational Research, 77(4), 575-614.

Lee, B., Isenberg, P., Riche, N. H., \& Carpendale, S. (2012). Beyond mouse and keyboard: Expanding design considerations for information visualization interactions. IEEE Transactions on Visualization and Computer Graphics, 18(12), 2689-2698. 
Ma, J., \& Nickerson, J. V. (2006). Hands-on, simulated, and remote laboratories: A comparative literature review. ACM Computing Surveys (CSUR), 38(3), 7.

Means, B., Toyama, Y., Murphy, R., Bakia, M., \& Jones, K. (2009). Evaluation of EvidenceBased Practices in Online Learning: A Meta-Analysis and Review of Online Learning Studies. US Department of Education.

Morrison, G. R., Ross, S. M., Kemp, J. E., \& Kalman, H. (2010). Designing effective instruction 6th Edition. John Wiley \& Sons.

Mumtaz, S. (2000). Factors affecting teachers' use of information and communications technology: a review of the literature. Journal of Information Technology for Teacher Education, 9(3), 319-342.

Niess, M. L. (2005). Preparing teachers to teach science and mathematics with technology: Developing a technology pedagogical content knowledge. Teaching and Teacher Education, 21(5), 509-523.

Okolo, C. M., \& Bouck, E. C. (2007). Research about assistive technology: 2000-2006. What have we learned?. Journal of Special Education Technology, 22(3), 19-33.

Penuel, W. R. (2006). Implementation and effects of one-to-one computing initiatives: A research synthesis. Journal of Research on Technology in Education, 38(3), 329-348.

Persichitte, K. A., Tharp, D. D., \& Caffarella, E. P. (1997). The Use of Technology by Schools, Colleges and Departments of Education, 1996. American Association of Colleges for Teacher Education, Washington, DC.

Pittman, T. \& Gaines, T. (2015). Technology integration in third, fourth and fifth grade classrooms in a Florida school district. Educational Technology Research and Development, 63(4), 539-554.

Polly, D., Mims, C., Shepherd, C. E., \& Inan, F. (2010). Evidence of impact: Transforming teacher education with preparing tomorrow's teachers to teach with technology (PT3) grants. Teaching and Teacher Education, 26(4), 863-870.

Rutten, N., van Joolingen, W. R., \& van der Veen, J. T. (2012). The learning effects of computer simulations in science education. Computers \& Education, 58(1), 136-153.

Seo, Y.-J., \& Bryant, D. P. (2009). Analysis of studies of the effects of computer-assisted instruction on the mathematics performance of students with learning disabilities. Computers \& Education, 53(3), 913-928.

Shi, M., \& Bichelmeyer, B. A. (2007). Teachers' experiences with computers: A comparative study. Journal of Educational Technology \& Society, 10(2).

Shimizu, H., Yoon, S., \& McDonough, C. S. (2010). Teaching skills to use a computer mouse in preschoolers with developmental disabilities: Shaping moving a mouse and eyehand coordination. Research in Developmental Disabilities, 31(6), 1448-1461.

Smerdon, B., Cronen, S., Lanahan, L., Anderson, J., Iannotti, N., \& Angeles, J. (2000). Teachers' Tools for the 21st Century: A Report on Teachers' Use of Technology. Statistical Analysis Report. National Center for Education Statistics (ED), Washington, DC.

Smith, S. J., \& Okolo, C. (2010). Response to Intervention and Evidence-Based Practices: Where Does Technology Fit? Learning Disability Quarterly, 33(4), 257-272.

Smith, T. E., Polloway, E. A., Patton, J. R., \& Dowdy, C. A. (1990). Teaching Students with Special Needs in Inclusive Settings (3'ed.). New York: Pearson Education.

Stetter, M. E., \& Hughes, M. T. (2010). Computer-assisted instruction to enhance the reading comprehension of struggling readers: A review of the literature. Journal of Special Education Technology, 25(4), 1-16.

Taylor, R. L., Richards, S., \& Brady, M. P. (2005). Mental retardation: Historical perspectives, current practices, and future directions. New York: Pearson Education. 
The Assistive Technology Act (2004). Tech Act: Technology Related Assistance for Individuals with Disabilities Act. https://www.govinfo.gov/content/pkg/PLAW108publ364/html/ PLAW-108publ364.htm

Twyman, T., \& Tindal, G. (2006). Using a computer-adapted, conceptually based history text to increase comprehension and problem-solving skills of students with disabilities. Journal of Special Education Technology, 21(2), 5.

Wachs, J. P., Kölsch, M., Stern, H., \& Edan, Y. (2011). Vision-based hand-gesture applications. Communications of the ACM, 54(2), 60-71.

Wenar, C., \& Kerig, P. (2006). The developmental psychopathology approach. Developmental psychopathology. From infancy through adolescence (fifth ed.). NewYork: McGraw-Hill.

World Health Organization (2019). Assistive Technology. Retrieved from https://www.who.int/disabilities/technology/en/

Zhao, Y., \& Frank, K. A. (2003). Factors affecting technology uses in schools: An ecological perspective. American Educational Research Journal, 40(4), 807-840. 